\title{
Ecotourism Potentials of Xavi Bird Watching Sanctuary in Akatsi District of Ghana
}

\author{
Conrad-J. Wuleka Kuuder \\ Dept. of Ecotourism and Environmental Management \\ University for Development Studies \\ Nyankpala, Ghana \\ Email:ckuuder@yahoo.co.uk \\ Godfred Atitso Doe \\ Dept. of Renewable Natural Resources \\ University for Development Studies \\ Nyankpala, Ghana \\ Email:godfredatitso@yahoo.com \\ and \\ Evelyn Kuusozume Yirbekyaa \\ Dept. of Social Science Education \\ University for Development Studies \\ Wa, Ghana \\ Email:zume2010@yahoo.com \\ DOI:http://dx.doi.org/10.4314/gjds.v10i1\&2.5
}

\begin{abstract}
The paper discusses an investigation into a fast emerging niche in ecotourism, bird watching or avitourism, as a pastime. The Xavi Sanctuary is a community-based resource, the largest and most popular of its kind in Ghana. A sample size of 168 respondents was obtained using the Fisher and associates (1998) formulae for calculating sample size. The analyses of results revealed that the residents of Xavi were content with the direct employment offered by the project to some members of the community within sections of the industry. However, most of them also benefited indirectly through the sale of handicrafts while others benefited from tourists' donations to the local community and basic schools. These accruing benefits have inspired the local community to institute measures to safeguard the sanctuary in order to
\end{abstract}


improve their gains. The paper suggests that promoting domestic tourism by way of awareness creation in the local media and adding more activities to help immerse visitors into the community could help boost their ecotourism potentials.

KEYWORDS: Bird watching, Nature Sanctuary, Avitourism, Ecotourism, Community-based Tourism

\section{Introduction}

Ecotourism is more often confused with tourism. While tourism has been defined by Mathieson and Wall (1982) as the temporary movement of people to destinations outside their normal home and work places, ecotourism has no universally agreed definition as a result of the diversity of criteria, perspectives and philosophical standpoints. According to Beaumont (1998), ecotourism is a subset of nature tourism which is also a subset of tourism and that the definition is based on three key principles: natural setting, ecological sustainability and environmental education or interpretation as represented in Figure 1.

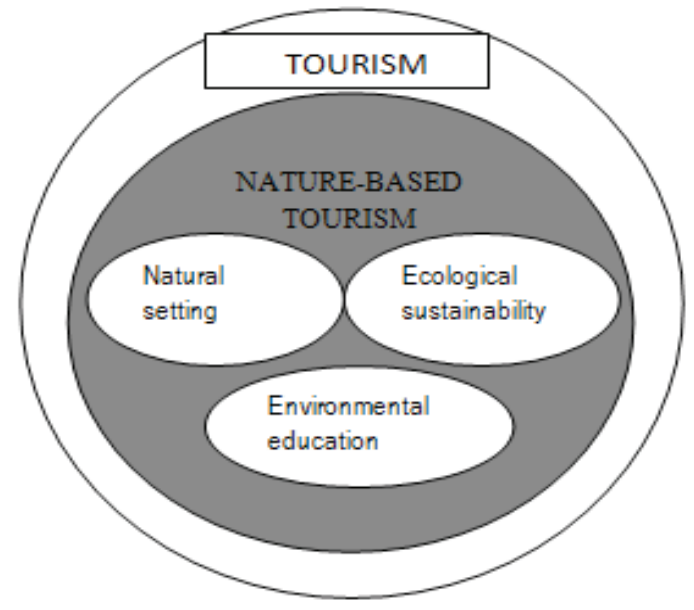

Figure 1: An inclusive approach to defining ecotourism using three key principles

Source: Beaumont (1998)

The World Conservation Union's (IUCN) definition cited in Ceballous-Lascurain (1996), states that ecotourism is environmentally responsible travel to relatively undisturbed natural areas, in order to enjoy and appreciate nature and any accompanying cultural features that promote conservation. It is said to have low visitor negative impact and to provide for the beneficially active socio-economic involvement of the local population. Both definitions therefore portray the varied standpoints in the meaning of ecotourism to people and organizations. 
A fast emerging market niche and a growing nature-based tourism (ecotourism) activity in the world today is birding/avitourism. In Ecuador, the establishment of eco-scenic birding trails in different habitats around the country is an important strategy of the Ecuadorian Ministry of Tourism to grab a piece of the pie offered by this niche (MindoCloudforest Foundation, 2011). In Africa, South Africa's KwaZulu Natal South Coast offers some of the best bird watching spots to be experienced in that country. In fact, the country's current avitourism market is between 21,000 and 40,000 avitourists annually, of which domestic avitourists' number between 13,000 and 24,000 per annum (http:southcoaststyle.co.za/ avi-tourism). Avitourism by definition is travel outside a person's usual environment for the purpose of viewing birds in their natural habitats. Since it is centred on components of the natural environment (i.e. birds and their habitats), avitourism is considered to be a subcategory of nature-based tourism. However, if avitourism adheres to sustainability principles it is also regarded as a component of ecotourism.

\section{Background}

Nature tourism is currently a hot cake the world over and in Costa Rica, for instance, Aylward and associates (1996) estimated that, this form of tourism generated over $\$ 600$ million in foreign exchange in 1994. In attempting to provide answers regarding the major factors contributing to the boom in this nature tourism/ecotourism 'drive', some authors have offered reasons such as an increased international awareness of global ecological realities, the desire among a rapidly growing and relatively affluent segment of the industrialized world's tourists to have nature-based experiences and the developing worlds' conviction that natural resources are finite and must be conserved for future generations (Hawkins, 1994; Page and Dowling, 2002). In Africa, Ankama (1996), in his analysis of nature-based tourism in Kenya, has indicated that approximately $10 \%$ of the country's natural area has been set aside for nature-based tourism, which accounts for $12 \%$ of Gross Domestic Product (GDP) and serves as a leading source of foreign exchange earnings.

The importance of wildlife to the people of Ghana is unquestionable. The country has 18 protected areas, 7 national parks, 6 resource reserves, 4 wildlife sanctuaries and one strict reserve all together occupying $13,048 \mathrm{~km}^{2}$ or $5.5 \%$ of the country's land size. There are about 222 known species of mammals of which ten are threatened and 721 bird species seven are threatened (Agyei-Ohemeg, 1991). Unlike the popularity that most national parks enjoy, bird sanctuaries or areas with avitourism related potentials tend to be least patronised by tourists for recreation purposes though they offer great forms of amusement. This study is based on the Xavi Community Bird Watching Sanctuary, which is located in the Akatsi District of the Volta Region. The area has outdoor activities in the form of bird watching and canoeing on the Lotor River. In addition, there is access to traditional historical sites such as the baobab grove. Like most studies on ecotourism destinations, this study sought to assess the sanctuary's potentials in terms of nature's variety culminating in its reptile and birdlife, the economic potentials and benefits to the 
local community, the efforts of the community at conservation, assessment of the level of visits to the sanctuary, impacts on the biophysical environment and the aspects of host culture available for making visitor experiences memorable.

\section{An Overview of Ecotourism Development}

The History of Ecotourism has been discussed by Lindberg and Mckercher (1997) and Fennell (1999) who suggested that it was only in the 1980s that ecotourism sought to find common ground due to the expansion of global tourism and the increasing interest in the natural environment. However, the phenomenon known as ecotourism was in existence long before the terminology became popular in tourism studies. Beaumont (1998) also opined that ecotourism is not new to western society - it has been around since at least the 18th century but by a different name. However, other experts that claim ecotourism originated in Muller's (1977) pioneering work on National Park Planning in Latin America. Still others trace its origins to the works of Hetzer (1965), who used the word ecotourism to explain the intricate relationship between the tourist, the environment and culture. The development of the concept of ecotourism grew according to Hetzer as a result of dissatisfaction with government and society's negative approach to development especially from an ecological point of view (Hetzer, 1965 cited in Bjork, 2000). Most developing countries are striving well in nature tourism especially in the realms of tourism's ability to impact on the lives of rural people who more often possess these communal attractions. Thailand, Kenya, Costa Rica, and others who are enormously endowed with natural products are successful promoters of ecotourism (Gowdy, 1997, Page and Dowling, 2002). In support of developing countries, especially with regard to their efforts in ecotourism, the United Nations Economic Social Council declared 2002 the International Year of Ecotourism (Vieta, 1996).

Ecotourism offers great opportunities and potentials such as employment and income to poor rural communities as well as improving infrastructure and balancing economic activities within the locality, when well managed (Bush, 2000). In the same light, Hovengaard (1994) has also indicated that ecotourism activities generate economic impacts on a global, national and local scale. Literature relating to avitourism also stipulates that this new niche (avitourism) provides environmental benefits to communities, helps to educate local residents on the values of biodiversity and offers incentives for the successful protection and preservation of natural areas. Bird watching is becoming the most rapidly growing and most environmentally conscious segment of ecotourism and provides economic hope for many threatened natural areas around the world (South African Department of Trade and Industry, 2010).

Similarly, Mackinnon, (1986) and Boo (1993) also indicate that ecotourism invariably brings social and economic effects to the communities where the sites are located such as the selling of souvenirs, provision of bed and boarding facilities to visitors, provision of employment opportunities, stimulating local markets and improvement 
in transportation and communication systems among others. However, Haenn (1994) differs in opinion by stating that tourist visits to a natural environment changes it unequivocally and their mere presence challenges a destination's claim to being pristine and an unaltered environment. He argues that even a small number of ecotourists can have a large adverse impact and they may inevitably spoil the place for future ecotourism purposes. For example in Nepal the popular route from Namche Bazaar camp has become so littered that it is now called the "garbage trail." While it is obvious that economic impacts may be measured and quantified to identify financial and employment effects, social and cultural impacts on visitors and host communities are often only considered when tourism development leads to local opposition. Cunningham and Saigo (1995) state that insensitive tourists tend to defile sacred places and offend local sensibilities by their behaviour. Ecotourism poses threats to indigenous cultures as it claims to preserve and "enhance" local cultures. On the contrary, evidence shows that in South Africa, with the establishment of protected areas, local people have illegally lost their homes, and most often with no compensation while the gross violation of the fundamental rights and environmental hazards far outweigh the medium-term economic benefits (Kamuaro, 1996).

Despite these setbacks brought in the wake of promoting this new phenomenon in the tourism literature, ecotourism has been identified as a viable tool for achieving sustainable development (Obua and Harding, 1996). Chase (1998) states that ecotourism in developing countries creates growing opportunities for enhancing resource conservation and economic growth. It also encourages the improvement of structure and balance of economic activities within the locality while boosting entrepreneurial activities. It is increasingly being used by many national and local governments as a mechanism to aid the regeneration of ailing economies and in less developed countries (LDCs) to stimulate economic development (Page and Dowling, 2002).

Ecotourists and researchers visit ecotourism centres for various reasons such as recreation, information and materials or specimen search. The number of competing sites and opportunities has expanded within and between countries leading to cultural appreciation. Ecotourism is also seen as a source of revenue to offset declining public sector subsidies for conservation management. In some cases, it replaces and resuscitates declining economic activities. A case in point is the Caribbean Coast village called of Tortuguero. According to Lee and Snepenger (1992), historically, Tortuguero's economy thrived on sea turtle harvesting, logging and small-scale agriculture but tourism is now its major value because of the establishment of Tortuguero National Park. The social and cultural impacts of ecotourism are less visible and more intangible unlike the economic impacts which can be measured and quantified to identify financial and employment effects unless the social and cultural values have negative effects on the people or when tourism development leads to local opposition (Murphy, 1985, cited in Page and Dowling, 2002). 


\section{History and Attractions of Study Area}

Xavi is a community in the Akatsi District of Volta Region (Ghana).The Community Bird Watching Sanctuary is 12 kilometres away from Akatsi, the district capital. The Xavi Bird Watching Sanctuary Project came into being in the year 2000. According to an 'account' of a tour guide and the chief of Xavi, the idea to establish the sanctuary was "hatched" by him (the chief) to enable the forest and the Lotor River area to be conserved. The Lotor River is believed to house a crocodile (Elo, - a local deity) which they worship as a river god. Through the efforts of the chief, The Akatsi District Assembly, The Wetlands Department, the Nature Conservation Research Centre (NCRC) based in Accra, the Ghana Tourism Authority (GTA) regional office in Ho, the US Peace Corps-Ghana, the Netherlands Development Organization (SNV) and the US Forestry Service assisted the community financially and with other logistics in conserving the forest and Lotor River area now the sanctuary site. The baobab grove was also discovered and developed later as an attraction and added to the tour package and experience of the bird watching sanctuary. The sanctuary and baobab grove are sited in two different areas in the locality. Within the sanctuary, there is a forest on the riparian zone of the Lotor River where visitors are given a ride in a locally dugout canoe along the river to watch the different creatures in the forest such as birds (see plates 1 and 2) and snakes. The river is about $12 \mathrm{~km}$ in length with the forest along the river banks. The baobab grove covers about 3 hectares where shades and seating units are provided for tourists to use as rest stops. Local people entertain the visitors within the grove with agbadza and kenka drums and dances (see plate 3). Other local music is provided on request.

\section{Methodology}

The total population of the town is 1,161 with males being 502 and female 659 (Ghana Statistical Service, 2000).

\section{Data and sources}

Primary data was sourced from respondents through a questionnaire survey. The impacts of such sustainable tourism projects are more apparent in a rural than an urban setting (Long, Perdue and Allen, 1990). The stakeholders in tourism comprise mainly of visitors, residents, local business owners and local government officials (Goeldner and Ritchie, 2003). All categories of respondents selected for the study fell within this classification. The selection of the community members was based on both probability and non-probability methods. The technique made use of the Ghana Statistical Service, 2000 Population and Housing Census (PHC) list for households where the selection of household heads was based on the use of the simple random method, basically employing the lottery method. Others such as chiefs, members of management boards, assemblymen and women, tour guides who held key information within the community were purposively selected. With those who had no formal education, the questionnaire 
was translated to them in the local dialect (Ewe) and their responses recorded. The literate ones responded to the questionnaire on their own. They had a two week period to respond after which their scripts where picked up. A total of 46 tourists (3o foreign and 16 domestic) were met accidentally over a one month period (April 1 to May 1, 2011) and information sourced from them.

\section{Sample Size Determination}

When the population of an area is less than 10,000, Fisher and associates (1998), state categorically that the desired sample size is calculated by the formula:

$n_{f=} \frac{n}{1+\frac{n}{N}}$, where

$n_{f}=$ the desired sample size ( when population is less than 10,000),

$n=$ the desired sample size (when population is greater than 10,000),

$N=$ the estimate of the population size

But to determine $\mathrm{n}_{\mathrm{f}} \mathrm{n}$ would have to be calculated. According Fisher et al, when the population is greater than 10,000 the sample size is determined by:

$\mathrm{n}=\mathrm{z}^{2} p q$

$d^{2}$

Where:

$n=$ the desired sample size (when the population is greater than 10,000)

$z=$ the standard normal deviation, usually set at 1.96 (or more simply 2.0) which corresponds to 95 percent confidence level

$p=$ the proportion in the target population estimated to have particular characteristics

$q=1.0-p$

$d=$ degree of accuracy desired, usually set at 0.05 or occasionally at 0 .

Assuming the target population aware of the tourism resources in the destination area is $85 \%$, (this community possesses attractions: bird sanctuary and baobab grove and a house to house survey was done and about $85 \%$ in the community were aware of the attractions and tourism 
activities) the $\mathrm{z}$ statistic being 1.96 and desired accuracy at 0.05 percent, then the sample size is:

$$
\begin{aligned}
& n=(1.96)^{2} \\
& 0.05^{2} \\
& n=196
\end{aligned}
$$

Therefore the sample size for the study was determined by:

$$
\begin{aligned}
& n_{f=} \frac{n}{1+\frac{n}{N}} \\
& n_{f}=\text { the desired sample size (when population is less than 10,000), } \\
& n=196 \\
& \begin{array}{c}
N=1,161 \text { (the population of Xavi community, obtained from Ghana Statistical } \\
\text { Service, 2000 Population and Housing Census) } \\
\frac{196}{1+196} \\
1,161
\end{array}
\end{aligned}
$$

The desired sample size for the study was calculated to be 168 .

Data from the field revealed that the youth (about 80\%) formed majority of the respondents. The zeal with which they readily revealed information on the Xavi Bird Sanctuary Project was revealing of their passion and interest in its success. Again, most respondents were male household heads (75\%). It was only in the absence of male that female (25\%) responded. An overwhelming majority of respondents ( $81 \%$ ) were married and more than half of respondents (55\%) had no formal education. Farming (which also included fishing) was the predominant occupation (55\%) but about $30 \%$ also claimed to be in tourism related work as tour guides, management board members, canoe boys, weavers and caterers at the local lodge.

\section{Results and Discussions}

According to responses gathered from the field, the Xavi Bird Sanctuary Project had the following potentials: 


\section{Impacts of Sanctuary on Xavi Community}

Since the bird sanctuary project is young in scope and indeed small scale, it cannot be said to influence the cost of living as exists in rich tourism enclaves or regions where prices are high due to the influence of tourist dollars. Close to $94 \%$ of respondents (see Table 1) were of the view that tourism has had no inflationary impact on the community. Also, about $55 \%$ of the respondents said some employment opportunities have opened up for the youth in the area with about 15 of them working as tour guides and earning monthly stipends on commission bases, depending on the number of guests they take around. Community members who paddle canoes with visitors in the Lotor River also earn stipends. Others also earn income from the sale of handicrafts such as beads, kente (locally woven cloth) and 'abayaxa' (a decorated broom made from raffia). Entrance fees collected also go into the community's common fund ( $85 \%$ attest to this) for development projects. This corroborates the assertion that, ecotourism offers great opportunities and potentials to bringing employment and money to poor rural communities and also to improving infrastructure and balance economic activities within a locality when well managed (Colvin, 1996; Bush, 2000).

Close to 90\% also affirmed that most foreign tourists donated to the community mainly in the forms of used-clothes including educational and recreational materials (books, pens and footballs) to basic schools in the community. Majority (94\%) did indicate that government does not support the project financially. With specific reference to the sociocultural impacts, the respondents (host) affirmed that guests appreciated their culture, especially when the 'agbazda' dance was performed to visitors at the baobab grove (see Plate 3, on page 4) and were ready to pay to be entertained by residents. This element of cultural appreciation is enshrined in Ceballos-Lascurin's (1996) definition of ecotourism. Basic school children come on group tours to the sanctuary to appreciate and learn about nature's birdlife variety. Close to $87 \%$ of respondents indicated that such programmes were very essential for 'growing minds' and is more likely to inculcate in them the essence of conservation (the catch them young spirit). Such also attests to the fact that environmental education will improve with visits to these ecological sites.

\section{Table 1: Impact of the Bird Sanctuary Project on the Community ( $\mathrm{N}=168)$}

\begin{tabular}{|l|l|l|}
\hline ECONOMIC & YES & NO \\
\hline There is a rise in cost of living in the area (inflationary trends) & 06 & 94 \\
\hline Increase in employment opportunities in Xavi & 55 & 45 \\
\hline Money is injected into the local economy due to tourism activities & 70 & 30 \\
\hline Money is generated into the communal common fund & 85 & 15 \\
\hline Tourists donate to the community & 90 & 10 \\
\hline
\end{tabular}




\begin{tabular}{|c|c|c|}
\hline Government supports the Xavi Bird Sanctuary Project & 08 & 92 \\
\hline SOCIO-CULTURAL & YES & NO \\
\hline Cultural appreciation by the guests & 23 & 77 \\
\hline School children come on tour to the facility & 87 & 13 \\
\hline Sufficient infrastructure (roads, canoes, life jackets) at the site & 72 & 28 \\
\hline Diversion of resources at the administrative level & 54 & 46 \\
\hline $\begin{array}{l}\text { There is improvements in infrastructural development since } \\
\text { inception }\end{array}$ & 60 & 40 \\
\hline Environmental education has improved & 88 & 12 \\
\hline There is improved service delivery to tourists & 55 & 45 \\
\hline There is overcrowding at the site & 90 & 10 \\
\hline $\begin{array}{l}\text { People are leaving their traditional jobs in preference to tourism } \\
\text { related jobs }\end{array}$ & 11 & 89 \\
\hline Interventions exist in the Bird Sanctuary Project & 97 & 03 \\
\hline BIOPHYSICAL & YES & NO \\
\hline The sanctuary is rich in birdlife and reptiles & 98 & 02 \\
\hline Tourism leads to disturbance of fauna at the site & 68 & 32 \\
\hline There is decrease in the aesthetic value of the area & 58 & 42 \\
\hline Tourism affects the vegetation in the area & 62 & 38 \\
\hline Tourism brings about a decrease in water quality & 19 & 71 \\
\hline $\begin{array}{l}\text { Tourism has brought conservation awareness to both tourists/host } \\
\text { alike }\end{array}$ & 84 & 16 \\
\hline Tourism in Xavi has brought in environmental education & 94 & 06 \\
\hline
\end{tabular}

Source: Field survey, 2011

About 90\% of respondents thought that the site was not overcrowding and that residents were not abandoning their traditional jobs (farming) to scramble for tourism related ones. Also 97 attested to the fact that interventions existed in the Xavi Bird Watching Sanctuary Project of the Akatsi District. 


\section{Impacts on Biophysical Environment}

With regard to impacts on the biophysical environment, the rich bird and reptile life of the sanctuary was agreed to by most respondents (98\%). Table 2 depicts a list (variety) of some birds and reptiles of the area (also see plates 1 and 2).
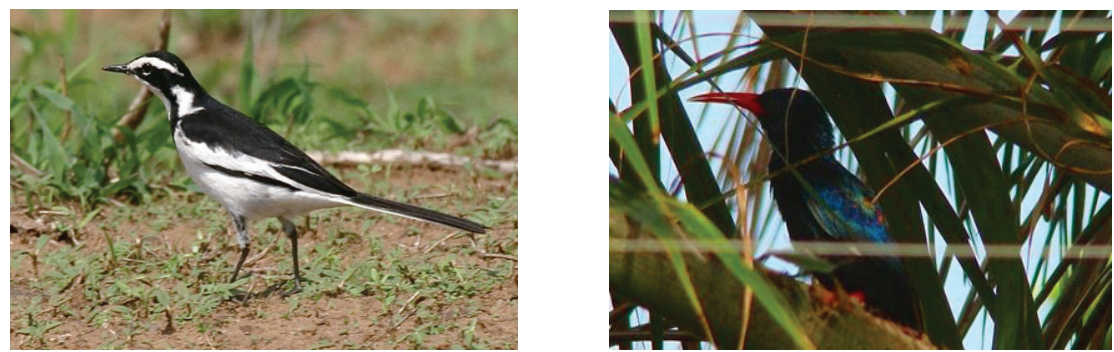

Plate 1: African Pied Wagtail Bird (mtacillaaguimp) Plate 2: Green Wood Poopoe (phoenicusluspurpureus)

Respondents were also of the view that birdlife of the area was in a way disrupted by the presence of visitors. The movement of people within the sanctuary was a sure way of disturbing their feeding, breeding, resting and roosting habits (68\% attested to this). The vegetation according to them was also affected through trampling as a result of the paths created for use as tour trails. However, the South African Department of Trade and Industry (2010) opines otherwise and wrote that avitourism when compared to other outdoor activities that fall within nature-based tourism has a lower environmental impact and should be promoted. Despite the shortfalls which are inevitable in every ecotourism project, some respondents (86\%) said the resource had raised conservation awareness among hosts and guests alike. As Chase (1998) has stated, ecotourism in developing countries creates growing opportunities for enhancing resource conservation and economic growth.

Table 2: Names of Some Birds and snakes found in Xavi Bird Watching Sanctuary

\begin{tabular}{ll}
\hline Names of some common birds & Scientific Names \\
\hline African pied wagtail & Mtacillaaguimp \\
Beared barbet & Lybiusdubius \\
Blue billed roller & Malimbusnitens \\
Brown babbler & Turdioidesplebejus \\
Common bulbul & Pyconotusbarbatus \\
Common swift & Apusapus \\
Copper sunbird & Nectariniacuprea
\end{tabular}




\begin{tabular}{ll} 
Goliath Heron & Ardeagoliath \\
Green wood poopoe & Phoenicusluspurpureus \\
Little egret & Egrettagarzetta \\
Klaa's cuckoo & Chrysococcyxklaas \\
Moho & Hypergerusatricpes \\
\hline Names of some common snakes & Scientific Names \\
\hline Yellow mamba & \\
African rock python & Python sebae \\
Puff adder & Viperaberus \\
Water snake & Nerodiaspp
\end{tabular}

Source: Xavi Bird Watching Sanctuary Tourist Information Office, (2011)

\section{Resource Protection Options}

The local community has instituted by-laws that bind community members and rules and regulations to be followed by guests, which aim at ensuring the sustainability of the sanctuary. The community members are aware of the by - laws and the consequences in case of default. At the Tourist Information Office at Xavi, visitors are given a briefing on rules and regulations while on site; the tour guides implement the rules to the latter. This is in consonance with Tyohino's and Hyones' (2001) position that ecotourism brings conservation of biological and cultural diversity through ecosystem protection. Hence, ecotourism means tourism with an ecological conscience that contributes to the maintenance of species and their habitats (Goodwin, 1996). Figure 2 depicts some of the resource protection options instituted by the community. 
Figure 2: Measures instituted by community to protect resource

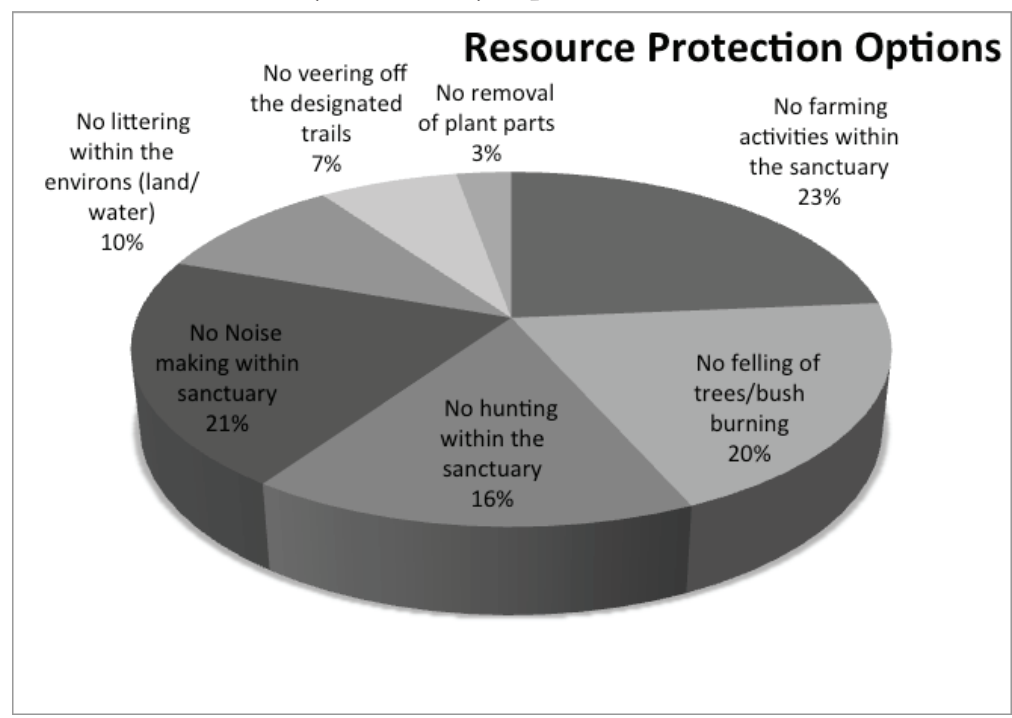

Source: Field survey, 2011

\section{Tourists Expectations}

A total of 46 tourists comprising 30 foreign and 16 domestic were contacted accidentally at the site. The foreign tourists were basically from Europe and North America and had been in Ghana on vacation. Results depicted in Table 3 show that ten (10) of the domestic tourists were very satisfied, two (2) were satisfied and four (4) were neither satisfied nor dissatisfied with their experiences at the Sanctuary. In the case of the foreign tourists, sixteen (16) were very satisfied while fourteen (14) did register their satisfaction.

Table 3: Level of satisfaction expressed by tourists on visiting the site

\begin{tabular}{lllllll}
\hline & $\begin{array}{l}\text { Very } \\
\text { satisfied }\end{array}$ & Satisfied & $\begin{array}{l}\text { Neither } \\
\text { Satisfied nor } \\
\text { dissatisfied }\end{array}$ & Dissatisfied & $\begin{array}{l}\text { Very } \\
\text { dissatisfied }\end{array}$ & Total \\
\hline Domestic & 10 & 2 & 4 & - & - & 16 \\
Foreign & 16 & 14 & - & - & - & 30 \\
Total & 26 & 16 & 4 & - & - & 46
\end{tabular}

Source: Field survey, 2011 
Reasons advanced included the availability of a variety of reptiles and birds, the opportunity to ride a canoe along the fringes of the river were also refreshing and the display of impressive agbadza drums and dance. See Plate 3

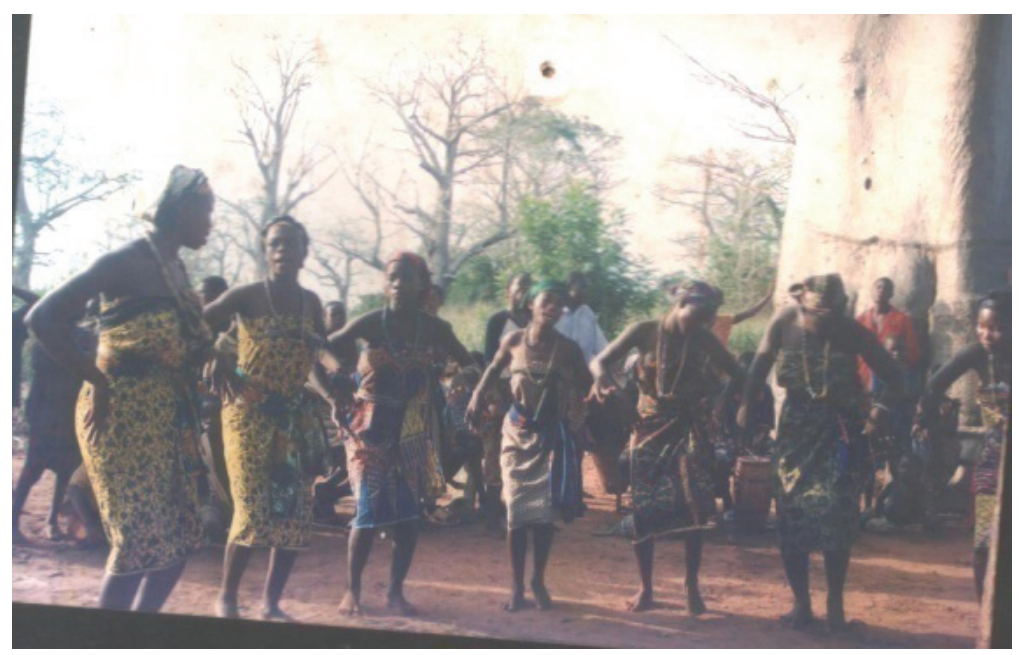

Plate 3: Indigenes performing 'agbadza' dance to welcome tourists at the baobab grove

Ten (10) of the foreign tourists indicated their willingness to share their experiences with friends and relations back home. Both domestic and foreign tourists commented that the price was within reach. Table 4 indicates the fees charged per domestic and foreign visitor to the two sites (Bird sanctuary and baobab grove).

Table 4: Current Fees charged per visitor

\begin{tabular}{|l|l|}
\hline Tourist Site & Fees charged per person $\mathrm{GH}_{\boldsymbol{\Phi}}$ \\
\hline Bird Watching Sanctuary (Ghanaian) & 5.00 \\
\hline Bird Watching Sanctuary (Non-Ghanaian) & 10.00 \\
\hline Baobab grove (Ghanaian) & 3.00 \\
\hline Baobab grove (Non-Ghanaian) & 5.00 \\
\hline
\end{tabular}

Source: Xavi Bird Watching Sanctuary Tourist Information Office, 2011

Figure 3 depicts the levels of patronage of the site since 2005. The figures shows that nonGhanaians have patronize the facility more than natives, except the year 2010 when the reverse was the case. The decline in visits by foreigners is attributed to the exit of the US Peace Corps-Ghana, who supported the project logistically and marketed the facility among volunteers. 
Figure 3: Domestic and foreign arrivals to the Bird Watching Sanctuary

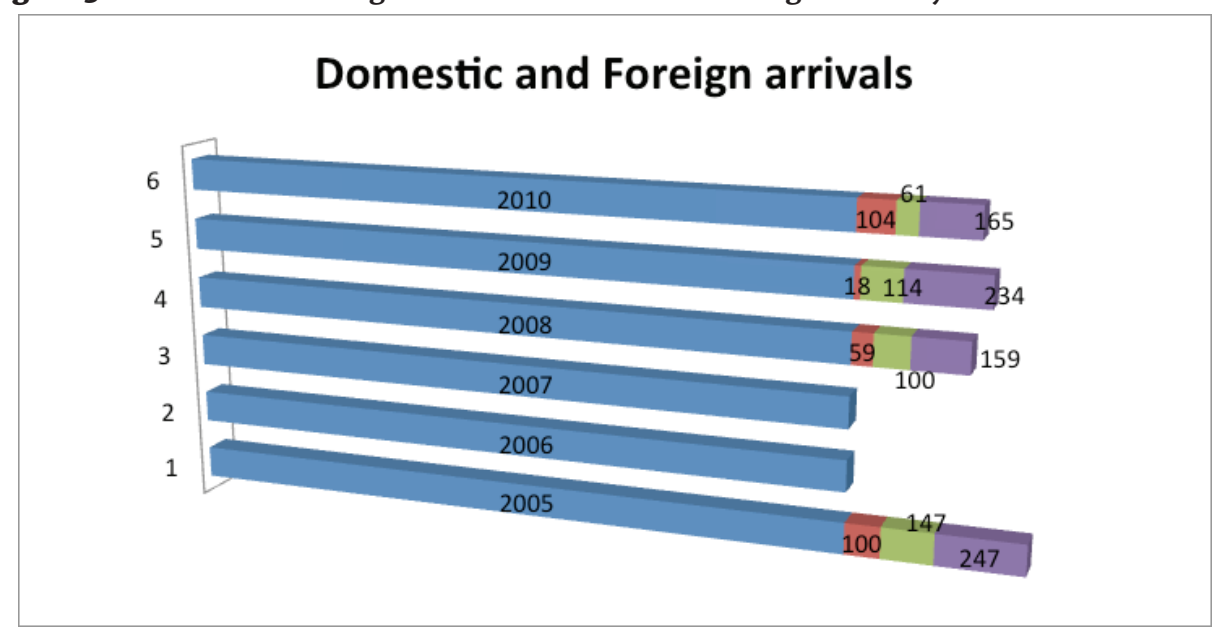

Series 1-years, Series 2-domestic arrivals, Series 3-Foreign Arrivals, Series 4-Total of domestic and foreign arrivals

Source: Xavi Bird Watching Sanctuary Tourist Information Office, (2011).

No figures were available for years 2006 and 2007

\section{Conclusion/Recommendations}

Bird watching is an interesting pastime but indigenous Ghanaians, majority of who live in rural and natural environments tend to ignore because it is part of their everyday experience. The birdlife in the Xavi Sanctuary is promisingly diversified and is yet to gain popularity as an emerging market niche. It has great potentials in bringing enormous income to the local people if a rigorous marketing agenda is pursued. Ecotourism projects tend to emphasize sustainability. It is in this regard that the community has put in punitive measures that are aimed at conserving the resource for generations. The promotion of domestic tourism through the local media (awareness campaign) should be seriously pursued. Environmentally oriented governmental and non-governmental agencies, individual philanthropists, citizen associations and the Akatsi District Assembly could assist the community with funds and logistics, which will enable them to develop field guides and bird hides. This should enable tourists to get close the birds. Such memorable experiences are more likely to lead to positive word of mouth publicity of the locality which may have the long term effect of drawing more visitors to the site. 


\section{References}

Agyei-Ohemeng, J. (1991). Bridging the Gap between man and Wildlife, The Dilemma of Ghana Nature and Fauna. International Journal of Nature Conservation in Africa, 7: $23-28$

Aylward, B., Allen, K., Echeverria, J \& Tosi, J. (1996). Sustainable Ecotourism in Costa Rica: The Monteverde Cloud Forest Reserve. Biodiversity and Conservation, 5:315-343

Beaumont, N. (1998). 'The meaning of ecotourism according to ....is there now consensus for defining this 'natural' phenomenon? An Australian perspective', Pacific Tourism Review, 2 (3): 239-250.

Bjork, P. (2000). Ecotourism from a conceptual perspective, an extended definition of a unique tourism form. The International Journal of Tourism Research, 2:189-202

Boo, E. (1990). Ecotourism: The potentials and pitfalls. Washington DC: World Wildlife Fund

Bush, B.M. (2000). Ecology of a changing planet, $2^{\text {nd }}$ Edition, Prentice Hall Inc.

Caballos-Lascurain, H. (1996). Tourism, Ecotourism, and Protected Areas. Gland: International Union for Conservation of Nature and Natural Resources.

Chase, L.C. (1998). Ecotourism Demand and Differential Pricing of Natural Parks, Access in Costa Rica, Journal of Land Economics, 74(4): 466-482.

Colvin, J. (1994). Capirona: A model of indigenous ecotourism, Journal of Sustainable Tourism 2(3): 174-177.

Cunningham, W. P. \& Saigo, W. B. (1995). Environmental Science, a global concern. 3rd Edition. Dubuque: Wm. C Brown Publishers

Fennell, S. (1999). Ecotourism: An introduction. London: Routledge.

Fisher, A.A.; Laing, J.E.; Stoeckel, J.E., \& Townsend, J.W. (1998). Handbook for Family Planning Operations Research Design. New York: Population Council.

Goeldner, C.R. \& Ritchie, J.R.B. (2003). Tourism Principles Practices and Philosophies, $9^{\text {th }}$ edition. New Jersey: John Wiley and Sons Inc.

Goodwin, H. (1996). In pursuit of ecotourism, Biodiversity and Conservation, 5(3): 277-291

Gowdy, J. M. (1997). The Values of Biodiversity, Market Society and Ecotourism, Journal of Land Economics, 73 (1): 25-41

Ghana Statistical Service (2000). Population and Housing Census, Accra: GSS.

South African Department of Trade and Industry (2010). Avitourism in South Africa: Opportunities and Recommendations, Johannesburg: Department of Trade and Industry. 
Haenn, N. (1994). 'A new tourist, a new environment: can ecotourism deliver?' Trends, 31 (2): $28-30$

Hawkins, D. (1994). Ecotourism: opportunities for developing countries. In W.

Theobald (ed.). Global Tourism: The next decade: Butterworth-Heinemann pp. 261-273

Hovengaard, G. (1994). Ecotourism: A status report and conceptual framework, Journal of Tourism Studies, 5(2): 24-35

Kamauro, O. (1996). Ecotourism: Suicide or Development? Voices from Africa No. 6: Sustainable Development, UN Non-Governmental Liaison Service. United Nations News Service

Kumar, P. (1996). Research Methodology. Addison Wisley; Longman Australia Pty Ltd.

Lee, D. \& Snepenger, D. (1992). An ecotourism assessment of Tortuguero, Costa Rica, Annals of Tourism Research 19 (2): 367-370.

Long, P. T.; Perdue, R. R. \& Allen, L. (1990). Rural Residents Perceptions and Attitudes by Community Level of Tourism, Journal of Travel Research, 28(3):3-9.

Lindberg, K. \& Mckercher, K. (1997). 'Ecotourism: a critical overview.' Pacific Tourism Review, 1(1): 65-79.

Mackinnon J.K. (1986). Managing Protected Areas in the tropics, IUCN GLAND, Switzerland: pp209

Mandocloudforest Foundation (2011). Birding and Bird Habitat Conservation/ Restoration in the Ecuadorian Andes. Retrieved September 20, 2011 from http:/ www.mindocloudforest.org/

Mathieson, A. \& Wall, G. (1982). Tourism: Economic, Physical and Social impacts. Harlow: Longman.

Obua, J. \& Harding, D. (1996). Visitor characteristics and attitudes towards Kibale National Park, Uganda. Tourism Management, 17(7): 495-505.

Page, S.J. \& Dowling, R. K. (2002). Ecotourism. Harlow: Prentice Hall

Tyohino, A. \& Hynones, A. (2001). "Ecotourism - imagery and reality. Reflections on concepts and practices in finished rural tourism" Nordia Geographical Publication, 21-34

Vieta, F.E. (1986). Ecotourism Propels Development. Journal of Africa Recovery, 13 (1):18-19. 